\title{
The Impact of Attribute Preferences on Adoption Timing: The Case of Photo-Voltaic (PV) Solar Cells for Household Electricity Generation
}

\author{
Towhidul Islam $^{\mathrm{a}}$ and Nigel Meade ${ }^{\mathrm{b}}$ \\ ${ }^{a}$ Department of Marketing and Consumer Studies University of Guelph, Ontario, Canada \\ ${ }^{\mathrm{b}}$ Imperial College Business School, London SW7 2AZ, UK
}

Islam, T. and N. Meade (2013), Impact of Attribute Preferences and Attitudinal Constructs on Adoption Timing: The Case of Solar Photo-Voltaic (PV) Cells for Household Level Electricity Generation, Energy Policy, 55, 521-530.

\begin{abstract}
We are concerned with micro-generation, individual households generating electricity using a renewable energy technology. We focus on modelling the adoption probability of photovoltaic solar panels by a household. Using data collected from an area of Canada where a generous feed-in tariff is available to households generating electricity from solar panels, we measure household level preferences for panels and use these preferences along with household characteristics to predict adoption time intentions. We use recent developments in measuring household level preferences for innovations via discrete choice experiments and establish a causal link between the attributes of the technology and adoption time intentions using discrete time survival mixture analysis. Significant preferences included lower cost, greater energy savings and lower fossil fuel inflation. Estimation of hazard probabilities showed that the significant preferences had intuitively reasonable effects. The hazard probabilities allow us to compute cumulative probability of adoption over a ten year period per household. Technology awareness has a significant effect on the adoption probability, reinforcing the need for effective education. Our approach indicates the level of heterogeneity in preferences, particularly high for investment criteria and $\mathrm{CO}_{2}$ emissions. These findings suggest that education campaigns should explain more about investment criteria, feed-in tariffs and environmental effects.
\end{abstract}

Keywords: Attribute preferences, Discrete Choice Experiments, Discrete-time survival mixture analysis 


\section{Introduction}

Growing energy demand, finite fossil fuel supplies, worries about energy security and environmental concerns are all factors encouraging the increasing use of renewable resources for electricity generation. Here, we are concerned with micro-generation, where individual households generate electricity using a renewable energy technology. This is a potentially very significant energy source as individual households account for one third of all energy consumption in USA (see Stern, 1992). We focus on the adoption of photo-voltaic solar panels by households. Data are gathered about the intentions and preferences of households to discover the determinants of whether households will adopt a solar panel installation and, if so, when they are likely to do so.

Energy policy analysis tends to prioritize technology and cost reduction considerations over a detailed understanding of household preferences. As noted by Stern (1992), the technical economic style of analysis is indispensable, but is lacking in both conceptual tools and understanding of how households (and social systems) can be changed to achieve policy objectives. The diffusion of new micro-generation technologies, such as photo-voltaic solar panels, is generally thought to be slow due to the conflict between the economic costs and the environmental benefits. In one of the more attractive markets, the residential sector, where individual households generate electricity on a small scale (less than $10 \mathrm{kWh}$ ), the resource and environmental advantages of photo-voltaic cells over conventional technologies are substantial even though costs are high. A combination of technological innovation, increased efficiency and economies of scales are likely to drive costs down. However, a dilemma for policy makers is how to accelerate the diffusion of this promising and environmentally friendly technology that is, at present, uncompetitive with respect to costs.

One of the possible reasons for slow adoption is that policy decisions are made by governments while adoption decisions are made by householders. In spite of $90 \%$ of cost covered by grants and with break-even period of only 3 years, photo-voltaic solar panels were not adopted as expected by Dutch households (see Jager, 2006). Technical economic feasibility is a necessary condition but further insights are needed into households' attribute preferences, their energy conservation motives, their knowledge and their access to information. The decision of a householder to install a micro-generator, such as a solar panel will be driven by a desire to be green, by socio - economic and cultural factors, governmental incentive schemes, cost and benefit issues, the choice of technology will be influenced by the local geography of the household.

The primary objective of this research is to aid policy makers by linking two critical uncertainties of new technology: (1) whether households prefer the attributes of new technology? and (2) when are they going to adopt (if at all)? Specifically, we measure household level preferences for photo-voltaic solar panels and use these preferences along with household characteristics (i.e. socio-demographics and attitudinal constructs) to predict adoption time intents for solar panels. Our study uses recent developments in measuring household level preferences for innovations via discrete choice experiments and establishes a causal link between the attributes of the technology and adoption time intentions using discrete time survival mixture analysis.

The structure of the paper is as follows: after a brief description of solar PVs in Section 2. In Section 3, we review the literature on the diffusion of renewable technologies, discuss the barriers to diffusion and the incentives offered; as a result of this discussion we formulate several hypotheses for examination. The methodology underlying our analysis is explained in Section 4. The data and the experimental design are described in Section 5. The results of our analysis are presented in Section 6. We conclude in Section 7. 


\section{Micro-generation technology: solar photo-voltaic cells}

Photo-voltaic systems convert sunlight directly into electricity; an overview of this technology is given by Green (2000). During their operation, photo-voltaic solar panels generate no $\mathrm{CO}_{2}$ emissions, the environmental impacts are caused by emissions generated during the production of the solar panels and during their disposal. Solar power is used to generate electricity via two technologies, photo-voltaic (PV) cells and central receiver thermal power plants. At present the use of PV technology is more widespread and has the smallest generating unit of the technologies, the adoption process of these photo-voltaic solar panels is the topic of this study. Photo-voltaic solar panels can be used to power small appliances and larger systems can create enough energy to take a home off the electrical grid. Photo-voltaic solar panels can be connected to home for supplemental power, full power and backup supply (off-grid), or as a revenue generating power system. In Canada, Ontario Power Authority's micro-FIT (Feed in Tariff) program will pay 80.2 cents $/ \mathrm{kWh}$ from roofmounted photo-voltaic solar panels and 64 cents/KWh for ground mounted panels. Currently Ontario households pay from 5.9 to 10.7 cents/KWh depending on the time of consumption, thus it is attractive to sell generated power to Ontario Power Authority (OPA) under a 20 years fixed contract. This gives a unique opportunity to install solar energy while making reductions in carbon emissions of about $400-1000 \mathrm{~g} / \mathrm{kWh}$ plus the opportunity to generate revenue. Although other forms of micro-generation technologies are available, such as wind power and biomass, we concentrate on photo-voltaic solar panels as they are relatively well known and their installation is feasible in many properties, both urban and non-urban.

\section{Literature Review, incentives and barriers, some hypotheses}

The diffusion of household photo-voltaic solar panels will be driven by endogenous factors (e.g. awareness of technology and desire for energy conservation) and exogenous factors such as costs, regulatory and market structure and characteristics of the technology. The promotion of household level electricity generation should also be socially acceptable as it requires incentives and subsidies from the tax payer.

Jacobsson and Lauber (2006) concluded that environmentally friendly solar energy is the best choice for generating electricity from the perspective of social costs but its successful takeoff will mostly depend on achieving lower economic costs. Allen et al. (2007) discuss in detail the costs, advantages and disadvantages of different types of micro-generation. They indicate that in the UK, even with incentives, micro-generation is uncompetitive in terms of payback periods. This is because the current market structure does not take into account the externalities of fossil fuels such as the impact of climate change and uncertainty in long run supply. As these new technologies move along the technology learning curve, the cost of production will reduce to become competitive with existing energy sources. In order to allow learning to take place in the current marketplace, governments can use several policy instruments to encourage market actors to make the large-scale investments in environmentfriendly technologies. In the case of photo-voltaic solar panels, the marginal cost has fallen by 35\% (see Allen et al., 2007). However, Jaffe and Stavin (1994) found that if purchase costs (including subsidies) were perceived to be falling, the adoption decision was likely to be postponed. Several researchers have found that energy prices have a significant effect on adoption behaviour. Long (1993) in an analysis based on US households showed that for a $1 \%$ rise in the energy prices, there is $0.21 \%$ rise in the adoption of conservation items. Jager-Waldau (2007) found that the dramatic oil price increases in 2005 led to a remarkable re-evaluation of the renewable energy sector by political and financial institutions.

One of the possible reasons for the slow adoption of micro-generation using renewable energy is the lack of information about available technologies. In their study of 
the diffusion of flat solar panels in Greece, Sidiras and Koukios (2004) found energy saving awareness to be one of the main factors explaining market growth. Social psychologists and marketing professionals know that information and knowledge are more likely to accelerate energy conservation behaviour when they are specific and personalized (see, for example, Borgida and Nisbett, 1977). Many current energy information programs failed due to lack of psychological and marketing insights. Examples include the failure to use marketing techniques for information acceleration such as video programs illustrating the process of electricity generation from solar PVs (Urban et al. 1996; Urban et al. 1997). Green electricity generation at household level is primarily positioned as an alternative supply technology but international experience suggests there is also a benefit on the demand side. When examining UK solar PV households, Keirstead (2007) found that a household experiences a 'double dividend'. The monitoring equipment for electricity imported (from the grid) and electricity generated by the installed PV technology allows householders to make further cost savings by modifying their electricity usage, on average, by $6 \%$. A further dividend is the saving in carbon emissions relative to existing fossil fuel sources.

Feed-in laws have two parts: an obligation on grid operators to buy all renewable electricity generated, and a pricing scheme i.e. a feed-in tariff (FIT) or export premium, guaranteed for a number of years. Munoz et al. (2007) summarize details of the harmonization of feed in laws in the European Union as a support market mechanism to accelerate diffusion of renewable energy. They find that the fast diffusion of renewable energy in Germany is mainly due to strong support policies, especially feed-in tariff laws. Wustenhagen and Bilharz (2006) found that FITs had a positive impact as the primary drivers of the diffusion of photo-voltaic solar panels. Similarly, Guidolin and Mortarino (2010) in their analysis of photo-voltaic systems of 11 countries found that government policy incentives made a significantly contribution to diffusion.

Various studies have shown certain consumer segments are more likely to adopt micro-generation renewable technologies and energy conservation behaviour. Household income is a dominant predictor for larger energy conservation investments (see Long, 1993; Kasulis et al., 1981; Poortinga et al., 2003; Walsh 1989). Education level is positively correlated with both energy use and energy conservation investments (Held 1983). The effect of age is a matter of debate: Walsh (1989) found that older households are less likely to make investments in energy conservation investments; Hirst and Goeltz (1982) found that young and elderly households make fewer investments than those in their middle ages. However, Keirstead (2007) reports that adopters of photovoltaic technology in the UK were, compared to the national average; older, wealthier, better educated and more likely to own their own home. Stern (1992) finds that household knowledge of renewable technologies and their attitudes toward energy conservation interact with other financial factors in the adoption decision.

Our research objective is to link household level attribute preferences to adoption time intentions. This review has identified multiple drivers for the diffusion of photo-voltaic solar panels. In Table 1, we have chosen attributes that are concrete and absolute with respect to each driver identified. We have also listed hypotheses in Table 1, these proposed hypotheses are based on the literature and will inform our modelling and the analysis of our results. 
Table 1. Identification of Attributes associated with the drivers of the diffusion of photo-voltaic solar panels

\begin{tabular}{|c|c|c|}
\hline Drivers & Attributes : & id hypotheses \\
\hline Cost Related & Hypotheses & $\begin{array}{l}\text { Total initial investment including installation and connection to national grid } \\
\text { Payback period } \\
\text { Adoption times for households will be earlier if: } \\
\text { if households are less price sensitive } \\
\text { less sensitive to longer payback periods }\end{array}$ \\
\hline $\begin{array}{l}\text { Environmental } \\
\text { benefits }\end{array}$ & Attributes & $\begin{array}{l}\text { Energy cost saving } \\
\text { Saving in carbon emission } \\
\text { Adoption times for households will be earlier if households have a higher } \\
\text { preference for } \\
\quad \text { energy cost saving } \\
\text { higher preference to save } \mathrm{CO}_{2} \text {. }\end{array}$ \\
\hline $\begin{array}{l}\text { Market } \\
\text { Development } \\
\text { \& Policy }\end{array}$ & Attributes & $\begin{array}{l}\text { Tax Incentives \& Grants } \\
\text { Export reward - (pass all or excess capacity to national grid) } \\
\text { Possibility of government policy changes about green energy technologies } \\
\text { Adoption times will be earlier for households which } \\
\text { have a higher preference for export rewards } \\
\text { see government policy changes as positive towards micro- } \\
\text { generations of technologies. }\end{array}$ \\
\hline $\begin{array}{l}\text { Demand } \\
\text { Inducing } \\
\text { environment }\end{array}$ & Hypotheses & $\begin{array}{l}\text { Yearly inflation on fossil fuel cost } \\
\% \text { of local households already adopted one of these technologies } \\
\text { Adoptions times will be earlier } \\
\text { if fossil fuel inflation is higher } \\
\text { if more neighbouring households have adopted }\end{array}$ \\
\hline $\begin{array}{l}\text { Awareness of } \\
\text { photo-voltaic } \\
\text { technology }\end{array}$ & Hypothesis & Adoption times will be earlier if the household is more aware of the technology \\
\hline $\begin{array}{l}\text { Attitude to } \\
\text { Conservation: }\end{array}$ & Hypothesis & $\begin{array}{l}\text { Adoption times will be earlier if households' attitude towards energy } \\
\text { conservation is relatively strong }\end{array}$ \\
\hline $\begin{array}{l}\text { Socio- } \\
\text { demographics: }\end{array}$ & Hypotheses & $\begin{array}{l}\text { Adoption times will be earlier if households: } \\
\text { are educated to a higher level } \\
\text { are in their middle age } \\
\text { have higher income. }\end{array}$ \\
\hline
\end{tabular}

\section{Methodology}

In this section, we discuss our methodology for calibrating the attribute preferences and for modeling the time to adoption. We model attribute preferences using a discrete choice model. We use discrete-time survival mixture analysis (DTSMA) to model the hazard probability of adoption at a given time in the future. The two modeling approaches will be discussed in turn.

\subsection{Discrete Choice Modelling}

The root of this modeling approach is random utility theory (see Manski, 1977); each individual has a latent preference or utility for each choice option available. Each individual seeks to maximize their utility by choosing the most preferred option. The latent preference is driven by two components: the observed attributes and the unobserved effects. Model development has mainly been concerned with modeling the heterogeneity of the unobserved effects. We follow the model proposed by Fiebig et al. (2010), the Generalized Multinomial Logit Model (G-MNL). This model is the latest in a series of developments based on the 
seminal work of McFadden, 1974; extended by Swait and Louviere, 1993, and Revelt and Train, 1998.

The utility to person $n$ from choosing alternative $j$ in the choice scenario $t$ is given by,

$$
U_{n j t}=\left[\sigma_{n} \beta+\gamma \eta_{n}+(1-\gamma) \sigma_{n} \eta_{n}\right] x_{n j t}+\varepsilon_{n j t},
$$

where the observed component is $x_{n j t}$ is a vector of observed attributes of alternative $j, \beta$ is a vector of utility weights (homogenous across consumers) which is to be estimated. Heterogeneity is subdivided into that caused by taste and by scale. The random variable $\sigma_{n}$ represents scale heterogeneity; this variable affects both the observed component and the unobserved taste, the random variable $\eta_{n}$ represents taste heterogeneity. The parameter $\gamma$ (between 0 and 1) governs how the variance of residual taste heterogeneity varies with scale in a model that includes both. The consumer's idiosyncratic error is $\varepsilon_{n j t .}$. The scale variable $\sigma_{n}$ is operationalized as a $\log$ normal distribution with mean 1 and standard deviation $\tau$.

To capture the effect of heterogeneity on the probability of a particular choice, Monte Carlo simulation is used, over $D$ iterations, the probability of person $n$ making choice $j$ is:

$$
P\left(j \mid X_{n t}\right)=\frac{1}{D} \sum_{d=1}^{D} \frac{\exp \left(\sigma^{d} \beta+\gamma \eta^{d}+(1-\gamma) \sigma^{d} \eta^{d}\right) X_{n j t}}{\sum_{k=1}^{J} \exp \left(\sigma^{d} \beta+\gamma \eta^{d}+(1-\gamma) \sigma^{d} \eta^{d}\right) X_{n k t}}
$$

However, in our analysis we are more focussed on the possible time of adoption (described in the next section) and thus do not implement the calculation of the choice probabilities.

\subsection{Discrete-time survival mixture analysis (DTSMA)}

The hazard function is the most common representation of an event time distribution, the hazard $h_{t}$ is the probability that an event occurs in period $t$, given that it did not occur previously. In our model of the hazard probability we consider the effects of the covariates and consider heterogeneity in the respondents. We follow the approach of Muthén and Masyn (2005) and model the hazard probability for individual $n$ thus

$$
h_{n t}=1 /\left(1+\exp \left(\tau_{t}-\sum_{c} \omega_{c} x_{c n}\right)\right)
$$

The parameter, $\tau_{t}$, is the threshold for the hazard at time $t ; \tau_{t}$ and $\omega_{c}$ are estimated; $\left(x_{c n}, c=1,2, \ldots\right)$ are the covariates associated with household $n$ (including attribute preferences, attitudinal constructs and socio-demographic covariates). An advantage of this approach is its ability to model unobserved heterogeneity, the estimation of the discrete-logit model uses a latent categorical variable framework. The general hypothesis is that households can be divided into $\mathrm{K}$ classes. However, preliminary experimentation demonstrated that there was no statistical support for two or more latent classes, thus we present the model (3) without latent classes. For an application of DTSMA with multiple latent classes, see Islam and Meade (2011). In addition to modeling unobserved heterogeneity, this framework has several useful advantages over parametric hazard models (Tellis et al. 2003). These include: allowing the use of discrete adoption times; accounting for observed heterogeneity (e.g. socio-demographics), allowing for the incorporation of attitudinal constructs with measurement errors. 


\section{Data and experimental design}

We designed a discrete choice experiment (DCE) which was administered as part of a larger survey of a panel of consumers recruited from a large web panel provider. Study participants from Ontario, Canada were screened based on house ownership and nonownership of any micro-generation technologies. We also collected data on adoption time intentions, awareness of micro-generation technologies, attitudinal constructs and sociodemographics. Data for the final survey were collected from June 1 to June 15, 2011. A total of 372 respondents were approached, 74 of whom either declined or did not complete the survey; so the final sample for estimation included 298 completed questionnaires, a response rate of $80 \%$. This sample size was considered adequate for the purpose of the study.

The list of attributes and levels for solar technology is given in Table 2. The attributes follow from Table 1; the levels were chosen following extensive research using the information available to possible adopters from reviews of products, advertisements by retailers and information on relevant websites.

Table 2. Solar technology for household electricity production, their attributes and the levels used.

\begin{tabular}{|c|c|c|c|c|c|}
\hline No & FEATURES & \multicolumn{4}{|c|}{$\begin{array}{l}\text { Range of each feature that we have varied in subsequen } \\
\text { survey questions }\end{array}$} \\
\hline 1 & $\begin{array}{l}\text { Total initial investment including } \\
\text { installation and connection to national } \\
\text { grid*. }\end{array}$ & $\$ 20,000$ & $\$ 25,000$ & $\$ 30,000$ & $\$ 35,000$ \\
\hline 2 & Energy cost saving & $10 \%$ & $20 \%$ & $30 \%$ & $40 \%$ \\
\hline 3 & Saving in carbon emission & 0 & $\begin{array}{l}1.0 \text { tonnes of } \\
\mathrm{CO}_{2}\end{array}$ & $\begin{array}{l}2 \text { tonnes } \\
\text { of } \mathrm{CO}_{2}\end{array}$ & $\begin{array}{l}3 \text { tonnes of } \\
\mathrm{CO}_{2}\end{array}$ \\
\hline 4 & Payback period & 5 year & 10 years & & \\
\hline 5 & Tax Incentives \& subsidy/rebates & Grant $\$ 2500$ & $\begin{array}{l}\text { Refund of } \\
\text { HST }^{* *}\end{array}$ & & \\
\hline 6 & $\begin{array}{l}\text { Export reward as per micro-FIT } \\
\text { program (pass all or excess capacity to } \\
\text { national grid) }\end{array}$ & 64 cents $/ \mathrm{kWh}^{* * *}$ & 80 cents $/ \mathrm{kWh}$ & & \\
\hline 7 & Yearly inflation on fossil fuel cost & $3 \%$ & $6 \%$ & & \\
\hline 8 & $\begin{array}{l}\text { Possibility of government policy } \\
\text { changes about green energy } \\
\text { technologies }\end{array}$ & No & Yes & & \\
\hline 9 & $\begin{array}{l}\% \text { of local households already adopted } \\
\text { one of these technologies }\end{array}$ & $5 \%$ & $10 \%$ & & \\
\hline
\end{tabular}

"The cost varied in this research is based on $3 \mathrm{KWh}$ capacity. This $3 \mathrm{KWh}$ generation can meet average household demand.

** Harmonized Sales Tax,

*** 64 cents/KWh for Ground Mounted Panels and 80 cents/KWh for Roof Mounted Panels

\subsection{Discrete Choice Experiment (DCE) and Survey}

We used a relatively new approach to constructing DCEs due to Louviere et al (2008), who propose the construction of a set of profiles using an experimental design suitable for identifying particular forms of indirect utility functions. A Balanced Incomplete Block Design (BIBD) is used to assign the profiles to choice sets of a fixed size. There are 9 attributes considered, 3 attributes have 4 levels, 6 attributes have 2 levels; this gives $4^{3} \times 2^{6}$ (= 4096) possible profiles. From this number of possible profiles, we need a set of 16 to achieve orthogonality. We then use a BIBD to assign the 16 profiles to 20 choice sets that each have 4 options. Note that once the possible number of profiles is chosen, the need to construct a DCE of convenient length determines the size of the chosen set of profiles, the number of scenarios and the number of options within a scenario. 
Figure 1. A sample screen shot from survey (Choice set 1 of 20)

\begin{tabular}{|c|c|c|c|c|}
\hline Features & Option A & Option B & Option C & Option D \\
\hline $\begin{array}{l}\text { Total initial investment including installation and } \\
\text { connection to national grid (3KWh Capacity) }\end{array}$ & $\$ 35,000$ & $\$ 30,000$ & $\$ 30,000$ & $\$ 30,000$ \\
\hline Energy cost saving & $10 \%$ & $10 \%$ & $20 \%$ & $30 \%$ \\
\hline Carbon emission saving & 3 tonnes of $\mathrm{CO} 2$ & 2 tonnes of $\mathrm{CO} 2$ & 3 tonnes of $\mathrm{CO} 2$ & 0 \\
\hline Payback period & 5 years & 5 years & 10 years & 10 years \\
\hline Tax Incentives $\&$ subsidy/rebates & Refund of HST & Grant $\$ 2,500$ & Grant $\$ 2,500$ & Refund of HST \\
\hline $\begin{array}{l}\text { Export reward as per micro-FIT program (pass all or } \\
\text { excess capacity to national grid) }\end{array}$ & $\begin{array}{l}64 \text { cents/KWh, } \\
\text { Ground Mounted }\end{array}$ & $\begin{array}{l}80 \text { cents } / \mathrm{KWh} \text {, } \\
\text { Roof Mounted }\end{array}$ & $\begin{array}{l}64 \text { cents/KWh, } \\
\text { Ground Mounted }\end{array}$ & $\begin{array}{l}80 \text { cents/KWh, } \\
\text { Roof Mounted }\end{array}$ \\
\hline Yearly inflation on fossil fuel cost & $6 \%$ & $6 \%$ & $3 \%$ & $6 \%$ \\
\hline $\begin{array}{l}\text { Possibility of government policy changes about green } \\
\text { energy technologies }\end{array}$ & No & Yes & No & No \\
\hline $\begin{array}{l}\% \text { of local households already adopted one of these } \\
\text { technologies }\end{array}$ & $10 \%$ & $5 \%$ & $5 \%$ & $10 \%$ \\
\hline
\end{tabular}

\begin{tabular}{|l||l|||}
\hline $\begin{array}{l}\text { Q1. Which of the four options would you MOST likely } \\
\text { choose? }\end{array}$ \\
\hline $\begin{array}{l}\text { Q2. Which of the remaining three technologies you } \\
\text { would you LEAST likely choose? }\end{array}$ \\
\hline $\begin{array}{l}\text { Q3. Which of the two remaining technologies you would } \\
\text { you MOST likely choose? }\end{array}$ \\
\hline Q4. If you would choose none of the four options, check the box to the right: \\
\hline
\end{tabular}

Show All Options

Scenario 1 of 20

Submit

Table 3: Summary of the socio-demographic characteristics of the sample of 298 households

\begin{tabular}{|c|c|c|c|c|c|}
\hline \multicolumn{2}{|c|}{ Socio-demographics } & $\%$ & \multicolumn{2}{|l|}{ Socio-demographics } & $\%$ \\
\hline Gender & Male & 54.4 & Education & $\begin{array}{l}\text { High School or } \\
\text { Lower }\end{array}$ & 22.8 \\
\hline & Female & 45.6 & & College & 38.9 \\
\hline \multirow[t]{6}{*}{ Income $^{\mathrm{a}}$ (Can\$) } & $<40 \mathrm{~K}$ & 18.5 & & Bachelor & 27.5 \\
\hline & $40 \mathrm{~K}-54 \mathrm{~K}$ & 13.1 & & $\begin{array}{l}\text { Post Graduate } \\
\text { or Higher }\end{array}$ & 10.7 \\
\hline & $55 \mathrm{~K}-69 \mathrm{~K}$ & 19.5 & Area of House ${ }^{b}$ (Sq. ft.) & $\leq 2000$ & 53.0 \\
\hline & $70-84 K$ & 16.8 & & $2001-3000$ & 29.5 \\
\hline & $85 \mathrm{~K}-99 \mathrm{~K}$ & 14.4 & & $3001-4000$ & 11.1 \\
\hline & $100 \mathrm{~K}$ and More & 17.8 & & $>4000$ & 6.3 \\
\hline \multirow[t]{6}{*}{$\operatorname{Age}^{\mathrm{a}}$ (Years) } & $<29$ & 8.4 & Neighborhood & Urban & 48.3 \\
\hline & $30-39$ & 15.1 & & $\begin{array}{l}\text { Suburban \& } \\
\text { Rural }\end{array}$ & 51.7 \\
\hline & $40-49$ & 19.5 & & & \\
\hline & $50-59$ & 21.1 & & & \\
\hline & $60-69$ & 25.2 & & & \\
\hline & 70 or More & 10.7 & & & \\
\hline
\end{tabular}

${ }^{a}$ In subsequent analysis, we have replaced household's membership in a particular age and income range with the mid points and mean centered both the variables

${ }^{\mathrm{b}}$ We have regrouped this variable in subsequent analysis

The response task is a sequential choice process, for a series of scenarios respondents are instructed to choose the most preferred alternative out of four, then the least preferred out of three, the second most preferred out of the remaining two. Respondents were also asked to indicate if they would choose none of the 4 options. This method of preference elicitation provides more information i.e. full rank order of all the options that allows to estimate the 
model for each household and has less than 30\% sample size requirements to obtain same precision as from a multinomial logit model estimated from the most preferred choices (Scarpa et al. 2010). The average completion time those who completed the survey tasks was 25 minutes. A sample screen shot of the survey (choice set 1 out of 20 choice sets) is shown in Figure 1. The socio-demographic characteristics of the households sampled are reported in Table 3. We have confirmed that the income distribution is broadly consistent with that of Ontario. The respondents also provided information about their awareness of photo-voltaic technology and their attitudes to energy conservation. The actual questions used are given in the Appendix.

\subsection{Measuring Adoption Times by using intention questions}

During the very early stages of products or before their launch, self reported adoption time intentions can be used as a proxy for actual adoption times. The underlying belief that intentions are accurate predictors of people's behaviour has been discussed by several authors, (see Ittersum and Feinberg 2010; Silk and Urban, 1978; Young, DeSarbo and Morwitz, 1998). We follow Morwitz (1994) and elicit a households' adoption time intention by asking to check only one choice from a range: 1 year, 2 years, .., 9 years, $\geq 10$ years (censored in subsequent analysis). This response provides the dependent variable in the DTSMA.

\section{Analysis}

The analysis falls into three stage, the estimation of preferences for the attributes identified in Table 1 using G-MNL; the estimation of estimated preferences per household and finally the estimation of the hazard probabilities of adoption of solar panels over different time horizons.

\subsection{Estimation of Aggregate Attributes Preferences using G-MNL}

The results of G-MNL estimates are summarized in Table 4. For each level of each attribute, the estimate of $\boldsymbol{\beta}$ is given along with its $p$ value and a heterogeneity flag. The $p$ value indicates if the estimate is significantly different from zero (typically the estimate is regarded as significant if the $\mathrm{p}$ value is less than 0.05). The heterogeneity flag is used as a summary of the output of the G-MNL; it indicates when the standard deviation of $\eta_{n}$ the taste heterogeneity is sufficiently large to indicate that a non-negligible proportion of the respondents will have weighted the attribute with a different sign to the mean.

Remembering that the likelihood of adoption of solar panels decreases as utility decreases, we consider the mean estimates in Table 4. We see a common pattern for each feature: the expected utility decreases as the level becomes less attractive. For a given feature, the estimates change in an intuitively reasonable way. Expected utility: decreases as the cost of a solar installation increases; increases as energy cost saving increases; increases as emission savings increase. The effects of the benefits of solar panels as an investment on expected utility also behave intuitively reasonably. A shorter payback time is preferred; a grant is preferred to a HST refund; a higher export reward is preferred; lower fossil fuel inflation is preferred. Neither the event of a change in government policy nor the level of adoption of solar panels by neighbours have significant effects on utility.

The significant scale parameter, $\tau$, implies that there is a substantial amount of scale heterogeneity in the data. The value of $\gamma=0.34$ indicates that scale impacts both mean preferences, $\beta$, and preference heterogeneity, $\eta$. The heterogeneity flag indicates where there was a wide variation in response. For example, in the case of the cost of the installation some respondents will have indicated a preference for more expensive installations. There is evidence of wide variation in the responses concerning the investment attributes some 
respondents will have: indicated a preference for longer payback periods; preferred lower export rewards and a refund of HST rather than a grant. There is also some evidence of heterogeneity in responses regarding $\mathrm{CO}_{2}$ emissions. The heterogeneity with respect to cost may indicate some belief that a more expensive system is better in some way. However, the heterogeneity associated with the investment criteria may indicate a less than total comprehension of the implications of the different levels offered. Similarly some respondents may need clarification about the import and desirability of $\mathrm{CO}_{2}$ emissions.

Table 4: Model Estimates of GMNL and Model Fit

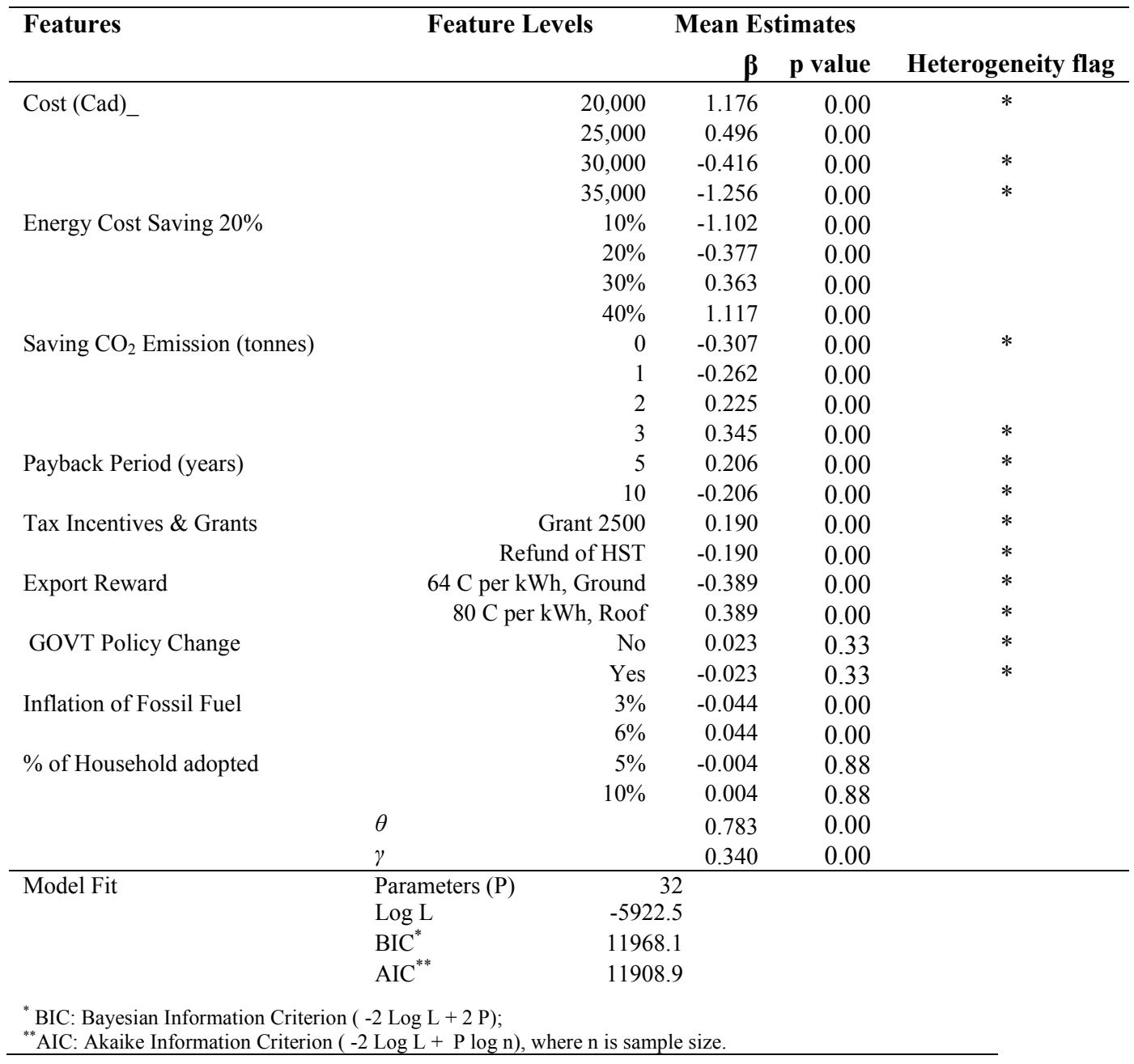

\subsection{Estimated preferences per household}

In order to use the results of the discrete choice experiment in the estimation of the hazard probability of adoption of solar panels over a given time horizon, we need to associate a set of estimated preferences for each household and their intended year of adoption. We estimated household level attributes preferences using a weighted least squares approach (WLS). This approach provided consistently superior in-sample and out -of-sample fit and is easy to implement, further it does not require assumptions about preference distributions, and hence is preferred on those grounds to approaches that do, see Louviere et al (2008) and Islam et al. (2009). The model estimates are suitably adjusted for unobserved variability. A sample distribution of household level preferences for 'energy cost saving' is shown in Fig 2. 
Figure 2. A histogram of estimated household preferences for Energy Cost Savings

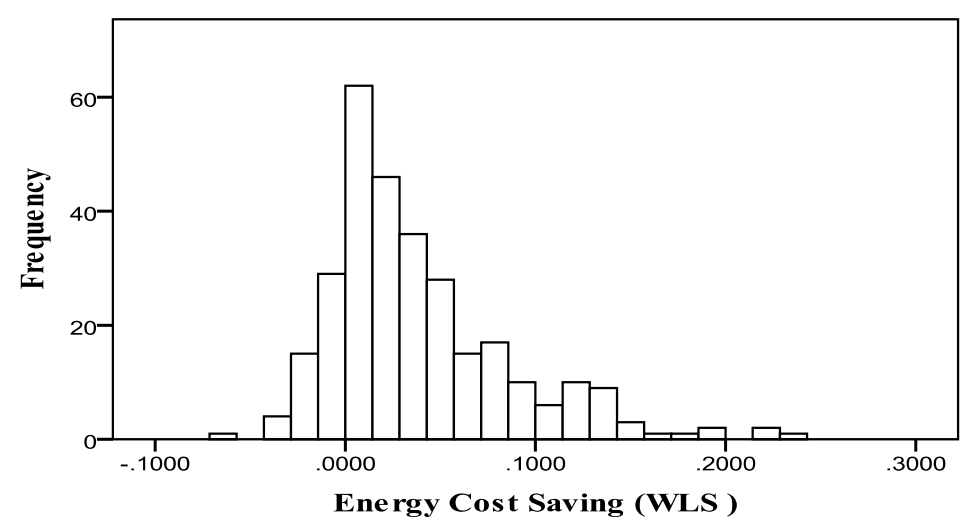

\subsection{Discrete time survival mixture analysis}

In our DTSMA we use several sets of covariates to model the hazard probabilities of the adoption of solar panels by a household. The first set of covariates contains the estimated preferences per household described in Section 6.2. The second set contains two attitudinal constructs; awareness of photo-voltaic technology and the household attitude to energy conservation (see Appendix). The third set reflects the socio-demographic data summarised in Table 2.

In its least parsimonious state, this model could have a hazard probability estimated for each year considered, i.e. one to nine years ahead. This implies nine separate threshold values, $\tau_{t}$. We used the Bayesian Information Criterion (BIC) to determine how few separate thresholds were needed. The results of the DTSMA are given in Table 5. The variables $X_{i}$ are either effect coded or mean adjusted in this analysis and as we can see from (3), a positive estimate of the coefficient, $\omega_{i}$, means that the hazard probability increases as the covariate, $X_{i}$, increases.

Table 5. Parameter estimates for adoption times for solar photo-voltaic panels: Results of Discrete Time Survival Mixture Analysis

\begin{tabular}{|c|c|c|c|}
\hline & & Est. & Sig. \\
\hline \multirow{9}{*}{$\begin{array}{l}\text { Attributes: Relate } \\
\text { of Solar PVs }\left(\omega_{\mathrm{x}}\right)\end{array}$} & Cost & 2.898 & 0.001 \\
\hline & Energy Cost Saving & 3.975 & 0.006 \\
\hline & Saving CO2 Emission & -0.136 & 0.578 \\
\hline & Payback Period (10 years) & 0.459 & 0.221 \\
\hline & Incentives (Return HST) & -0.184 & 0.663 \\
\hline & Export Reward (80c/KWh) & 0.530 & 0.002 \\
\hline & Inflation of Fossil Fuel (6\%) & -1.159 & 0.011 \\
\hline & Govt. Policy Change (yes) & 0.950 & 0.009 \\
\hline & $\%$ of Household adopted $(10 \%)$ & -0.642 & 0.203 \\
\hline \multirow{2}{*}{$\begin{array}{l}\text { Attitudinal } \\
\text { Construct }\left(\omega_{\mathrm{x}}\right) \\
\text { Awareness }\left(\omega_{\mathrm{x}}\right)\end{array}$} & Energy Conservation & 0.598 & 0.008 \\
\hline & Awareness & 0.407 & 0.000 \\
\hline \multirow{2}{*}{$\begin{array}{l}\text { Socio } \\
\text { demographics }\end{array}$} & Age & -0.306 & 0.000 \\
\hline & $\mathrm{Age}^{2}$ & -0.074 & 0.098 \\
\hline
\end{tabular}




\begin{tabular}{clcc}
\hline$\left(\omega_{\mathrm{x}}\right)$ & Household Income & -0.073 & 0.062 \\
& Education: Post-Grad. & 0.389 & 0.034 \\
& Education: Bachelor & -0.023 & 0.880 \\
& Education: College & -0.206 & 0.143 \\
& Gender: Male & 0.345 & 0.000 \\
& Location: Urban & 0.145 & 0.091 \\
& Size: $<=$ 2000 sq. ft. & -0.247 & 0.040 \\
& Size: $>$ 2000 sq. ft. & -0.163 & 0.224 \\
\hline Baseline & Year 1 - 2 & 4.457 & 0.000 \\
Hazards, & Year 3 - 5 & 2.847 & 0.000 \\
Threshold $\tau$ & Year 6 - 9 & 2.720 & 0.000 \\
(piece wise) & Y & \\
\hline${ }^{*}$ Baseline hazard probabilities, $1 /(1+\exp (\tau))$, baseline hazard probabilities are $\mathrm{h}_{1-2}=0.0115, \mathrm{~h}_{3-5}=0.0548$ and \\
$\mathrm{h}_{6-9}=0.0618$. We have used BIC to select the years to be combined in the piece-wise estimation of $\tau .$.
\end{tabular}

The results show clearly the negative impact of the price of a solar panel installation on adoption times. Those households who are above average in their tolerance of the cost of an installation have a higher probability of adoption. Similarly, those who have a strong preference for energy saving have a higher hazard probability. Neither the preferences for $\mathrm{CO}_{2}$ emissions nor the length of the payback period were significant. Households with a low tolerance of fossil fuel inflation (or an expectation of a change in government policy) have a higher probability of adoption. Greater awareness of the technology and more positive attitude to energy conservation leads to higher adoption probabilities. For the sociodemographic variables, the probability of adoption increases: if the household is younger; if the household income is below average; if the household is educated to a higher level; if the household occupies a large property.

In the context of a campaign promoting the use of photo-voltaic solar panels, both the level of awareness (dependent on advertising) and availability (dependent on distribution) are under managerial control. In the context of our survey, all respondents become aware of the technology; further it is assumed that the technology is available and suitable for the roof or the yard of their premises. In general, if the level of awareness is a proportion, $x$, and availability (including suitability) is a proportion, $y$, then the predictions of our survey need to be adjusted by a factor $x y$. The DTSMA allows us to calculate the cumulative probability of adopting a photo-voltaic solar panel by time $t$ for all the households considered. We calculate these probabilities and summarize them in Figure 3. The dispersion at the end of 10 years is very large with a $90 \%$ confidence interval between $10 \%$ and $98 \%$ of adoption having occurred within 10 years. The household associated with the $10 \%$ probability of adoption within ten years has an income around Can $\$ 90,000$, lives in a small rural property, the respondent is female educated to no more than high school level and is in her mid-fifties. The household associated with the $98 \%$ probability of adoption within ten years has an income over Can $\$ 100,000$, lives in a small urban property; the respondent is female educated to post-graduate level and is under thirty. This contrast is only part of the story, the attribute preferences also play an important role in establishing the probability of adoption. Note that the median level of adoption after 10 years, $52 \%$, is conditional on awareness and availability. Thus for a sub-population where awareness is $70 \%$ and availability is $50 \%$, the predicted median penetration is $18 \%$. 
Figure 3. Estimated cumulative probabilities of adoption (assuming full awareness and full availability): median value with $50 \%$ and $90 \%$ confidence intervals.

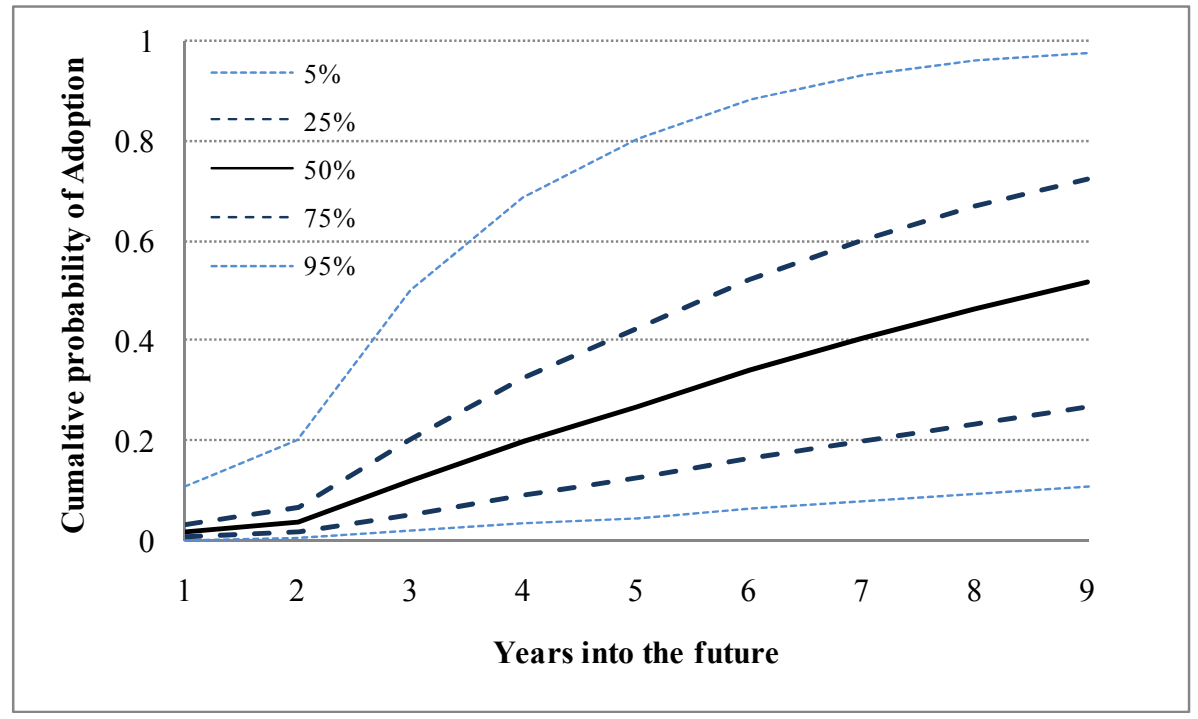

\section{Summary and Conclusions}

Our objective has been to model the adoption of photo-voltaic solar panels, the particular form of micro-generation that we considered. Since the adoption process is in its early stages we have based our methodology on the use of data describing the preferences and intentions of households. The data are collected from an area of Canada where a generous feed-in tariff is on offer to households generating electricity from solar panels. The methodology is in three stages: a discrete choice experiment where the respondents reveal their preferences for the attributes of solar panels; an estimation phase that provides expected preferences for each household; the use of discrete time survival mixture analysis to estimate hazard probabilities. These hazard probabilities allow us to compute the cumulative probabilities of adoption over a period up to 10 years for each household

The discrete choice experiment allowed us to estimate how household utility functions were affected by the different attributes of photo-voltaic solar panels. Expected utility was found to behave intuitively reasonably with respect to the cost of installation, energy cost saving, increase in emissions and payback time. There was no evidence of an imitation effect, since the proportion of neighbours adopting was not found significant.

In the estimation of household utility functions, in addition to judging the significance of covariate, our modelling approach indicated the level of heterogeneity in preferences. This proved particularly informative in respect to the investment criteria. For example, some households indicated a preference for longer payback periods. There was also evidence of heterogeneity in preferences with regard to $\mathrm{CO}_{2}$ emissions. These finding suggest that education campaigns should go beyond explanation of the technology and explain more about investment criteria, feed-in tariffs and environmental effects.

The estimation of hazard probabilities showed that the significant preferences had intuitively reasonable effects. Awareness of the technology had a significant effect on the probabilities of adoption, reinforcing the need for effective education campaigns. However preferences that were found significant in the estimation of the utility function but with high heterogeneity such as $\mathrm{CO}_{2}$ emissions and payback period were found insignificant. 


\title{
Appendix. Questions used to elicit information on awareness of photo-voltaic technology and attitude to energy conservation
}

\author{
Awareness \\ Regarding Solar Photovoltaic technologies, please tick the number that BEST describes your level of \\ awareness \\ $\begin{array}{lllllll}\text { Unfamiliar } & 1 & 2 & 3 & 4 & 5 & \text { Familiar }\end{array}$ \\ $\begin{array}{lllllll}\text { Not Knowledgeable } & 1 & 2 & 3 & 4 & 5 & \text { Knowledgeable }\end{array}$ \\ $\begin{array}{lllllll}\text { Inexperienced } & 1 & 2 & 3 & 4 & 5 & \text { Experienced }\end{array}$
}

\section{Energy Conservation Attitudes}

For each of the statements below, please indicate to what extent you agree (or disagree) with the statement on a 5 point scale where $1=$ strongly disagree; $2=$ disagree; $3=$ neither agree nor disagree $4=$ agree $5=$ strongly agree.

\section{Statement}

I always switch off lights in unused rooms

I leave electrically powered appliances (TV, Stereo, Printer) on standby

It should be mandatory to install energy-efficient heating system in new buildings

I wait until I have full load before doing my laundry

Everyone should use compact fluorescent bulbs

I buy energy efficient appliances

I put thermostat maximum at $18{ }^{\circ} \mathrm{C}$

\begin{tabular}{ccccc}
$\begin{array}{c}\text { Strongly } \\
\text { Disagree }\end{array}$ & \multicolumn{2}{c}{$\begin{array}{c}\text { Neither Agree } \\
\text { Nor Disagree }\end{array}$} & $\begin{array}{c}\text { Strongly } \\
\text { Agree }\end{array}$ \\
1 & 2 & 3 & 4 & 5 \\
1 & 2 & 3 & 4 & 5 \\
1 & 2 & 3 & 4 & 5 \\
1 & 2 & 3 & 4 & 5 \\
1 & 2 & 3 & 4 & 5 \\
1 & 2 & 3 & 4 & 5 \\
1 & 2 & 3 & 4 & 5
\end{tabular}




\section{References}

Allen, S. R., G.P. Hammond, M.C. McManus (2007), Prospects for and barriers to domestic microgeneration: A United Kingdom perspective, Applied Energy 85 (6) 528-544.

Borgida, E. and Nisbett, R. (1977), The differential impact of abstract vs. concrete information on decision, Journal of Applied Social Psychology, 7, 258-271.

Fiebig, D. G., Keane, M. P., Louveire, J. J. and Wasi, N. (2010), "The Generalized Multinomial Logit Model: Accounting for Scale and Coefficient Heterogeneity," Marketing Science, 29(3), 393421.

Green, M. A. (2000), Photovoltaics: Technology Overview, Energy Policy, 28 (14), 989-998.

Guidolin, M. and Mortarino, C. (2010), Cross-country diffusion of photovoltaic systems: modelling choices and forecasts for national adoption patterns, Technological Forecasting and Social Change, 77, 279-296.

Held, M. (1983), Social impact of energy conservation, Journal of Economic Psychology, 3 (3-4), 379-394.

Hirst, E., Goeltz, R. (1982), Residential energy conservation actions: analysis of disaggregated data. Energy Systems and Policy, 6(1), 135-150.

Islam, T. \& Meade, N. (2011). 'Detecting the impact of market factors on sales takeoff times of analog cellular telephones', Marketing Letters, 22 (2), 197-212.

Islam, T., Louviere, J. \& Pihlens, D. (2009). Aggregate Choice and Individual Models: A Comparison of Top-Down and Bottom-Up Approaches, Sawtooth Software Conference, March 23-27, Delray Beach, Florida, USA.

Ittersum, K. V. and Feinberg, F. (2010), Cumulative Time Intent: A New Perspective Tool for Technology Adoption. Journal of Marketing Research. XLVII (October), 808-822.

Jacobsson S, Lauber, V., 2006, The politics and policy of energy system transformation-explaining the German diffusion of renewable energy technology, Energy Policy, 34, 256-276.

Jaffe, A. and Stavin, R. (1994), The Energy Efficiency Gap: What does It Mean?, Energy Policy, 22, 804-811.

Jager, W. (2006), Stimulating the diffusion of photovoltaic systems: A behavioural perspective, Energy Policy, 34, 1935-1943.

Jager-Waldau, A. (2007) Photovoltaics and renewable energies in Europe, Renewable and Sustainable Energy Reviews, 11, 1414-1437

Kasulis, J., Huettener, D. and Dikeman, N. (1981), The feasibility of changing electricity consumption patterns, Journal of Consumer Research, 8(3), 279-290.

Keirstead, J. (2007), Behavioural responses to photovoltaic systems in the UK domestic sector, Energy Policy 35 4128-4141.

Long, J. (1993), An econometric analysis of residential expenditures on energy conservation and renewable energy sources, Energy Economics, 15(4), 232-238.

Louviere, J.J., Street, D., Burgess, L., Wasi; N., Islam, T., Marley, A.A.J. 2008. Modeling the Choices of Individual Decision-Makers by Combining Efficient Choice Experiment Designs with Extra Preference Information. Journal of Choice Modelling 1(1), 128-163.

Manski C., 1977, The Structure of Random Utility Models, Theory and Decision, 8, 229 - 254.

McFadden, D. 1974. Conditional Logit Analysis of Qualitative Choice Behavior. In P. Zarembka (ed.), Frontiers In Econometrics, Academic Press: New York, 105-142.

Morwitz, V. G. (1994), Predicting Whether and When Consumer Will Purchase From Intention Data, Working Paper, Stern School of Business, New York University.

Munoz,, M. Oschmann, V. and Tabara, J.D. (2007) Harmonization of renewable electricity feed-in laws in the European Union, Energy Policy 35 3104-3114

Muthén, B., Masyn, K. (2005). Discrete-time survival mixture analysis. Journal of Educational and

Behavioral Statistics, 30(1), 27-58.

Poortinga, W., Steg, L., Vleg, C. and Wiesma, G. (2003), Household preference for energy saving measures: a conjoint analysis. Journal of Economic Psychology, 24(1), 49-64.

Revelt, D. and Train, K. (1998), Mixed logit with repeated choices: households' choices of appliance efficiency level, Review of Economic Statistics, 80, 647-657. 
Scarpa, R., Notaro, S., Louviere, J. J. and Raffaelli, R. (2010), Exploring Scale Effects of Best/Worst Rank Ordered Choice Data to Estimate Benefits of Tourism in Alpine Grazing Commons, American Journal of Agricultural Economics, 93 (3), 809-824.

Sidiras D.K. and Koukios E.G. (2004) Solar systems diffusion in local markets, Energy Policy, 32 (18), $2007-2018$.

Silk, A. J. Urban, G. L. (1978), Pre-Test Market Evaluation of New Packaged Goods: A Model and Measurement Methodology. Journal of Marketing Research, 15 (May), 171-191. Stern, P. C. (1992), What psychology knows about energy conservation, American Psychologist, 47 (10), 1224-1232.

Swait, J., Louviere, J. (1993) The Role of the Scale Parameter in the Estimation and Comparison of Multinomial Logit Models. Journal of Marketing Research, 30, 305-314.

Tellis, G. J., Stremersch S., Yin E. (2003). The international takeoff of new products: The role of economics, culture and country innovativeness. Marketing Science. 22(2) 188-208.

Urban, G. L., Hauser, J. R., Qualls, W. J., Weinberg, B. D., Bohlmann, J. D. and Chicos, R. A. (1997). Information acceleration: validation and lessons from the field. Journal of Marketing Research, 4(1), 143-153.

Urban, G. L., Weinberg, B. D., \& Hauser, J. R. (1996). Premarket forecasting of really new products. Journal of Marketing, 60(1), 47-60.

Walsh, M. (1989), Energy tax credits and housing improvements, Energy Economics, 11(4), 275-284. Wustenhagen, R. and Bilharz, M. (2006), Green Energy Market Development in Germany Effective Public Policy and Emerging Customer Demand, Energy Policy, 34, 1681-1696.

Young, M. R., DeSarbo, W. S. and Morwitz, V. G. (1998), The Stochastic Modelling of Purchase Intentions and Behavior. Management Science, 44(2), 188-202. 